Review began 01/27/2022 Review ended 02/12/2022 Published 02/20/2022

๑) Copyright 2022

Al Ghadeer et al. This is an open access article distributed under the terms of the Creative Commons Attribution License CCBY 4.0., which permits unrestricted use, distribution, and reproduction in any medium, provided the original author and source are credited.

\section{Pediculosis Is a Risk Factor for Iron Deficiency Anaemia}

Hussain A. Al Ghadeer ${ }^{1}$, Fadi Busaleh ${ }^{1}$, Hassan M. Albahrani ${ }^{1}$, Alla M. Albisher ${ }^{1}$, Abdulaziz AlHassan ${ }^{1}$, Hassan M. AlAmer ${ }^{1}$, Hassan M. Alibrahim ${ }^{1}$, Ahmed H. Alherz ${ }^{1}$, Abdullah F. Al Muaibid ${ }^{1}$, Tawfiq M. Aljubran $^{1}$

1. Pediatrics, Maternity and Children Hospital, Al-Ahsa, SAU

Corresponding author: Hussain A. Al Ghadeer, hu.alghadeer@gmail.com

\begin{abstract}
Pediculosis capitis is obligate ectoparasite that lives and feeds on host blood, affecting commonly children. Lice are transmitted easily and respond to topical treatment with good personal hygiene. Chronic infestation can lead to different complications such as bacterial infection dermatitis and anaemia. Haematological complications are not reported frequently. We report a case series of five patients presented with a clear manifestation of anaemia with heavy lice infestation. Laboratory evaluation revealed microcytic hypochromic anaemia (red blood cell indices) with low serum iron levels and other causes that were excluded. All patients who were admitted received blood transfusions. There was not a possible explanation for this severe anaemia other than head lice.
\end{abstract}

Categories: Pediatrics, Infectious Disease, Hematology

Keywords: saudi arabia, alahsa, profound anaemia., iron deficiency anaemia, head lice, pediculosis capitis

\section{Introduction}

Pediculosis capitis, a common skin condition known as head lice, is considered a general public issue caused by Pediculus humanus (Pediculus humanus capitis) infestation. It is contagious and transmitted through direct contact (head-to-head) or indirect contact through sharing clothes, towels and other personal items [1]. Although it is affecting all age groups but is frequently seen in the first decade of life [2]. The prevalence of pediculosis depends on several factors: socioeconomic, demographic, educational, and hygiene [3]. Pediculus humanus is a holoparasite blood-feeding human ectoparasite that survives on its host [4]. This results in a blood loss of $0.7 \mathrm{~mL} /$ day. Although a small amount of blood loss is insignificant in a healthy child, chronic and heavy infestation causes significant blood loss that leads to anaemia [5].

No definitive relationship between iron deficiency anaemia and pediculosis has been found. Limited literatures reported iron deficiency anaemia in patients with heavy and chronic infestation without apparent cause of anaemia. This is the first case series in the paediatric age group that describes five siblings presented with profound anaemia due to lice infestation.

\section{Case Presentation}

This case series describes five female siblings aged between 6-13 years presented on the same day to a pediatric emergency department in Maternity and Children's Hospital, Al-Ahsa, Saudi Arabia. They live in an area that is $300 \mathrm{~km}$ away from Al-Ahsa with poor socioeconomic status. All of them did not know to have any significant medical or surgical illnesses and there was no family history of inherited, genetic or haematological diseases.

They had a similar clinical presentation with a history of generalized fatigability and pallor for one month (Table 1). It was associated with non-productive cough and pagophagia for four days and one of them had a syncopal attack lasting for a few minutes. It was also associated with head lice infestation for two weeks and subjective fever that responded to paracetamol. They denied any history of dyspnoea, syncope, dizziness, headache, change in bowel habit (diarrhea, constipation, bleeding) or urine (dysuria, frequency, urgency, proteinuria and hematuria). There was no history of ingestion of herbal or chemical medications. They had no history of weight loss, anorexia or eating disorder. They were not known to have an allergy neither they were on regular medication. 


\section{Cureus}

\begin{tabular}{|c|c|c|c|c|c|}
\hline & Patient A & Patient B & Patient C & Patient D & Patient $\mathrm{E}$ \\
\hline Age (years) & 6 & 8 & 12 & 12 & 13 \\
\hline \multicolumn{6}{|l|}{ Clinical features } \\
\hline \multicolumn{6}{|l|}{ Symptoms } \\
\hline Pallor & + & + & + & + & + \\
\hline Fatigability & + & + & + & + & + \\
\hline Dyspnoea & + & + & + & + & + \\
\hline Syncope & - & + & - & - & - \\
\hline Bleeding & - & - & - & - & - \\
\hline Menstrual cycle & - & - & - & - & +++ \\
\hline Headache & - & - & + & - & + \\
\hline Dizziness & - & - & + & - & + \\
\hline Pagophagia & + & + & + & + & + \\
\hline Palpitation & + & + & + & + & + \\
\hline Chest pain & - & - & - & - & - \\
\hline Weight loss & - & - & - & - & - \\
\hline \multicolumn{6}{|l|}{ Sings } \\
\hline Pallor & + & + & + & + & + \\
\hline Jaundice & + & + & + & + & + \\
\hline Tachypnoea & + & + & + & + & + \\
\hline Tachycardia & + & + & + & + & + \\
\hline Hypotension & - & - & - & - & - \\
\hline Active bleeding (from the scalp) & + & + & + & + & + \\
\hline Change in urine colour & - & - & - & - & - \\
\hline Hematemesis & - & - & - & - & - \\
\hline Organomegaly & - & - & - & - & - \\
\hline
\end{tabular}

\section{TABLE 1: The clinical presentation of the patients}

On examination, they looked ill, pale with dark spots distributed all over the body (blood on crust). Notable head lice infestation with copious nits on the scalp, which was associated with scratch marks with injured scalp, was identified. Their vital signs revealed tachycardia and tachypnoea, others were within the normal level. Systemic examination was unremarkable. There was no lice infestation on the rest of the body and pubis other than the head.

Laboratory tests revealed that all of them had a similar finding of microcytic hypochromic anaemia with mild anisocytosis (Table 2). The iron profile showed a low iron level which confirmed the diagnosis of iron deficiency anaemia. The stool culture test for occult blood and ova was negative. The biochemical and coagulation profile was normal. The test was negative for Heinz body, hemoglobin $(\mathrm{Hb}) \mathrm{H}$ disease.

\begin{tabular}{|l|l|l|l|l|l|l|}
\hline Laboratory tests & $\begin{array}{l}\text { Patient } \\
\text { A }\end{array}$ & $\begin{array}{l}\text { Patient } \\
\text { B }\end{array}$ & $\begin{array}{l}\text { Patient } \\
\text { C }\end{array}$ & $\begin{array}{l}\text { Patient } \\
\text { D }\end{array}$ & $\begin{array}{l}\text { Patient } \\
\text { E }\end{array}$ & \\
\hline Complete Blood Count $(\mathrm{CBC})$ & & & & & & Reference level \\
\hline
\end{tabular}




\section{Cureus}

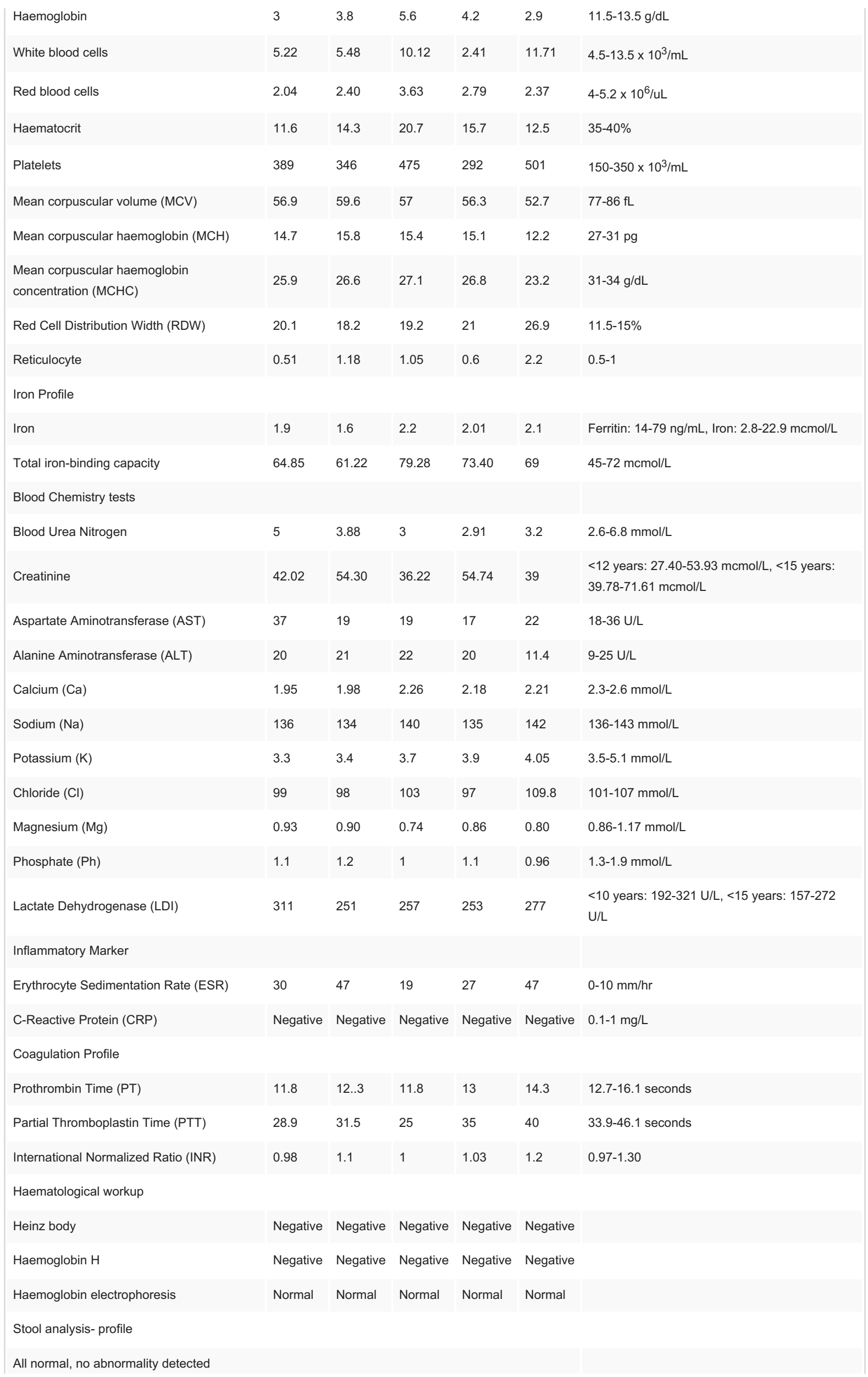




\section{Cureus}

TABLE 2: Laboratory investigations

They were initially admitted in the Paediatric Intensive Care Unit (PICU), received packed red blood cells (PRBCs) for normalization of haemoglobin levels. Then they were transferred to the general ward, and started on oral ferrous sulfate and folic acid for iron deficiency anaemia and showered with permethrin shampoo for head lice infestation. The patients were discharged on daily ferrous sulfate and permethrin shampoo with regular follow-up with Paediatric Infectious Diseases.

\section{Discussion}

Lice are obligate human ectoparasites that survive and complete their life cycle on the host's blood and favour humid areas [4]. There are two distinct types of lice species that need humans as a host. Pthirus pubis (pubic lice, carb lice), considered as a sexually transmitted disease (STD), predominantly infests genital hair. Pediculus humanus (P. humanus) is composed of two ecotypes: P. humanus corporis lice infest the body and P. humanus capitis lice infest the head $[6,7]$. Lice is a health issue worldwide due to its high prevalence and spread through direct or indirect contact. Female lice live up to 30 days on a host, deposit 10 nits daily and survive up to four days on objects that affirm their ease of transmission [1]. They usually affect the age group of 3-11 years particularly in females due to the culture of long hair [2]. In this current series, all of the patients were infested by pediculosis capitis, which are predominantly seen on heads, without apparent lice on other areas like the pubis or body. The patients are female siblings living within the same house and all of them had severe head lice except their parents. Lice are transmitted rapidly among children in the first decade of life through direct contact during playing, sleeping or through indirect contact during sharing personal items.

The clinical presentation of head lice is pruritis which leads to injured scalp, excoriation and lymphadenopathy. Complications of head lice resulting from parasitism are secondary bacterial infection, dermatitis, local post-therapeutic dermatitis and chronic anaemia. Diagnosis is established by the evidence of living lice, nits on hair shafts [8,9]. Dermoscopy is used to differentiate nits comprising nymphs from empty nits (pseudonymphs) [10]. All of our patients presented with symptomatic anaemia in the form of pallor, generalized fatigability, dizziness and pagophagia. Syncopal attack was seen in the elder sister (13 years old) during the period of menstruation, which exacerbated the symptom. As there is a concurrent head lice infestation, with the exclusion of other causes of anaemia, head lice are the causative reason of iron deficiency anaemia through chronic active blood loss by lice.

Management of head lice necessitates the elimination of living lice and nits. Non-pharmacological treatment consists of mechanical removal and combing with a nit comb every 2-3 days to prevent reinfestation. Ensure good personal hygiene, disinfection of clothes at a temperature greater than $53.5^{\circ} \mathrm{C}$ $\left(128.3^{\circ} \mathrm{F}\right)$ and other personal items shouldn't be shared. Pharmacological treatment consisting of applying topical pediculicide includes pyrethrins permethrin $1 \%$ lotion [11]. Although shaving of the scalp is a simple and effective method, it is not recommended because of psychological distress on the child [12]. At the time of presentation, all of our patients received packed red blood cells due to severe symptomatic anaemia and a significant drop in haemoglobin levels. Topical permethrin is applied and it is advised to repeat it after 10 days with general measurements to prevent reinfestation.

\section{Conclusions}

Iron deficiency anaemia is the most common type of anaemia worldwide. Usually, it is caused by dietary insufficiency, malabsorptive diseases like celiac disease or chronic blood loss as in gastrointestinal bleeding. Chronic blood loss is usually related to the gastrointestinal system due to inflammatory conditions or mechanical causes such as a gastric ulcer. Pediculosis capitis is a hematophagic organism that causes minimal blood loss, but a chronic infestation can be associated with a significant blood loss and presented with iron deficiency anaemia as presented in our case. This should alert the physician to correlate the relationship between chronic infestation and hematophagic organisms as a possible cause of iron deficiency anaemia.

\section{Additional Information \\ Disclosures}

Human subjects: Consent was obtained or waived by all participants in this study. Conflicts of interest: In compliance with the ICMJE uniform disclosure form, all authors declare the following: Payment/services info: All authors have declared that no financial support was received from any organization for the submitted work. Financial relationships: All authors have declared that they have no financial relationships at present or within the previous three years with any organizations that might have an interest in the submitted work. Other relationships: All authors have declared that there are no other relationships or activities that could appear to have influenced the submitted work. 


\section{Cureus}

\section{References}

1. Burkhart CN, Burkhart CG: Fomite transmission in head lice. J Am Acad Dermatol. 2007, 56:1044-1047. 10.1016/j.jaad.2006.10.979

2. Motovali-Emami M, Aflatoonian MR, Fekri A, Yazdi M: Epidemiological aspects of Pediculosis capitis and treatment evaluation in primary-school children in Iran. Pak J Biol Sci. 2008, 11:260-264. 10.3923/pjbs.2008.260.264

3. Nazari M, Fakoorziba MR, Shobeiri F: Pediculus capitis infestation according to sex and social factors in Hamedan, Iran. Southeast Asian J Trop Med Public Health. 2006, 3:95-98.

4. Veracx A, Rivet R, McCoy KD, Brouqui P, Raoult D: Evidence that head and body lice on homeless persons have the same genotype. PLoS One. 2012, 7 :e45903. 10.1371/journal.pone.0045903

5. Speare R, Canyon DV, Melrose W: Quantification of blood intake of the head louse: Pediculus humanus capitis. Int J Dermatol. 2006, 45:543-546. 10.1111/j.1365-4632.2005.02520.x

6. Badiaga S, Brouqui P: Human louse-transmitted infectious diseases . Clin Microbiol Infect. 2012, 18:332337. 10.1111/j.1469-0691.2012.03778.x

7. Sonthalia S, Varma S, Jha AK: Dermoscopy of pubic louse. Indian Dermatol Online J. 2019, 10:90-91. 10.4103/idoj.IDOJ_35_18

8. Meinking TL: Clinical update on resistance and treatment of Pediculosis capitis . Am J Manag Care. 2004, 10:264-268.

9. Nutanson I, Steen CJ, Schwartz RA, Janniger CK: Pediculus humanus capitis: an update. Acta Dermatovenerol Alp Pannonica Adriat. 2008, 17:147-159.

10. Badri T, Hammami H, Benmously R, Mokhtar I, Fenniche S: Dermoscopic diagnosis of pediculosis capitis . Acta Dermatovenerol Alp Pannonica Adriat. 2010, 19:45-46.

11. Sangaré AK, Doumbo OK, Raoult D: Management and treatment of human lice. Biomed Res Int. 2016, 2016:8962685. 10.1155/2016/8962685

12. Centers for Disease Control and Prevention. Head lice: treatment . (2018). Accessed: November 21, 2018 https://www.cdc.gov/parasites/lice/head/treatment.html. 